\title{
PENDAMPINGAN MANAJEMEN DAN TATA KELOLA MASJID SERTA LEMBAGA AMIL ZAKAT INFAK DAN SODAQOH
}

\author{
Hafiez Sofyani \\ Fakultas Ekonomi dan Bisnis \\ Universitas Muhammadiyah Yogyakarta \\ email: hafiez.sofyani@umy.ac.id
}

\begin{abstract}
The partners that invited to collaborate in community partnership activities are the Taqarrub Mosque Takis 1 Takmir and An-Nur Dusun Pakis 2 Mosque, and the Dlingo Village Head, Bantul Regency, Yogyakarta Special Region. The management of mosques and zakat through the Amil Zakat, Infak and Shodaqoh Institutions (LAZIS) at partner sites is still held traditionally and is not well organized. As a result of this, there was a community conflict triggered by the lack of transparency in the management of mosque finance and zakat. This is due to the level of understanding and competence of the Takmir Mosque which is a citizen of Pakis 1 and 2 which is inadequate. From this problem, a solution was proposed in the form of training and management assistance and governance of mosques and amil zakat infak and sodaqoh institutions. These activities include: drafting the bylaws, organizational structure, procurement of modules, guidelines, guidelines, and standard operating procedures for mosque management and LAZIS. From the results of the implementation of this program, it was concluded that there had been an increase in the quality of management and governance of the Taqarrub Mosque in Pakis 1 Hamlet and An-Nur mosque in Pakis 2, namely to be better and transparent. Conflicts related to bad prejudice arising from a small portion of the community regarding the management of mosque finance and LAZ can also be minimized.
\end{abstract}

Keywords: Management, Governance, Mosque, LAZIS

Mitra yang diajak kerjasama dalam kegiatan kemitraan masyarakat ini adalah Takmir Masjid Taqarrub Dusun Pakis 1 dan Masjid An-Nur Dusun Pakis 2, serta Lurah Desa Dlingo, Kabupaten Bantul, Daerah Istimewa Yogyakarta. Pengelolaan masjid dan zakat melalui Lembaga Amil Zakat, Infak, dan Shodaqoh (LAZIS) di tempat mitra masih diselenggarakan secara tradisional dan tidak tertata dengan baik. Akibat dari hal ini terjadilah konflik warga yang dipicu oleh tidak transparanyna pengelolaan keuangan masjid dan zakat. Hal ini disebabkan oleh adanya tingkat pemahaman dan kompetensi Takmir Masjid yang merupakan warga Pakis 1 dan 2 yang belum memadai. Dari permasalahan ini, maka diusulkan suatu solusi berupa kegiatan pelatihan dan pendampingan manajemen dan tata kelola masjid serta lembaga amil zakat infak dan sodaqoh. Kegiatan ini meliputi: penyusunan AD/ART, struktur organisasi, pengadaan modul, panduan, pedoman, dan Standar Operasional Prosedur pengelolaan masjid dan LAZIS. Dari hasil pelaksanaan program ini, ditarik simpulan bahwa telah terjadi peningkatan kualitas pengelolaan dan tata kelola masjid Taqarrub Dusun Pakis 1 dan masjid An-Nur di Pakis 2, yakni menjadi lebih baik dan transparan. Konflik terkait prasangka buruk yang muncul dari sebagian kecil masyarakat terkait pengelolaan keuangan masjid dan LAZjuga dapat diminimalisir.

Kata Kunci: Pengelolaan, Tata Kelola, Masjid, LAZIS 


\section{PENDAHULUAN}

Pentingnya akuntansi sejatinya tidak hanya diperuntukkan bagi lembaga bisnis, seperti perusahaan, tetapi juga lembaga Publik, seperti masjid dan Lembaga Amil Zakat atau biasa disebut LAZ (Ulum \& Sofyani, 2016). Menurut Hafidhuddin (2012) tidak dikelolanya suatu lembaga secara professional, termasuk masjid dan LAZ dapat memicu lahirnya konflik di masyarakat mengingat dana dari kedua lembaga tersebut berasal dari masyarakat. Konflik yang dimaksud seperti ketidakpercayaan masyarakat kepada pengelola atas manajemen keuangan lembaga (lihat juga: Chalikuzhi, 2009; Wahid et al., 2009).

Selaras dengan yang disampaikan Hafidhuddin (2012) fenomena ini Nampak nyata sebagaimana yang dihadapi oleh Takmir Masjid Taqarrub di Dusun Pakis 1 dan Masjid An-Nur di Pakis 2, Desa Dlingo, Kabupaten Bantul Daerah Istimewa Yogyakarta yang menjadi mitra dalam pengabdian masyarakat ini.
Berdasarkan hasil observasi dan wawancara kepada Lurah Desa Dlingo yang juga warga Pakis 2, kami menemukan bahwa dalam hal pengelolaan masjid dan zakat di Desa Dlingo, khususnya Pakis 1 dan 2 masih diselenggarakan secara tradisional dan tidak tertata dengan baik. Akibat dari hal ini terjadilah konflik warga yang dipicu oleh tidak transparanna pengelolaan keuangan masjid dan zakat. Hal ini disebabkan oleh adanya tingkat pemahaman dan kompetensi Takmir Masjid yang merupakan warga Pakis 1 dan 2 yang belum memadai. Akan tetapi, dari segi potensi masyarakat di Pakis 1 dan 2 cukup baik, hal ini dapat dilihat dari tertatanya struktur desa secara baik mulai level Desa, Dusun, Rukun Warga (RW), dan Rugun Tetangga (RT).

Tabel 1 pada paper ini menyajikan matriks permasalahan pengelolaan masjid di masjid Taqarrub dan An-Nur serta dampak yang terjadi seiring hadirnya masalah-masalah tersebut.

Tabel 1. Permasalahan Pengelolaan Masjid Taqarrub dan An-Nur Dusun Pakis 1 dan 2, Desa Dlingo, Kabupaten Bantul

\begin{tabular}{|l|c|l|l|}
\hline \multicolumn{1}{|c|}{$\begin{array}{c}\text { Masalah } \\
\text { Prioritas }\end{array}$} & \multicolumn{1}{|c|}{ Rincian Masalah } & \multicolumn{1}{c|}{ Dampak } \\
\hline $\begin{array}{l}\text { Pengelolaan } \\
\text { dan Tata } \\
\text { Kelola } \\
\text { Masjid }\end{array}$ & 1. & $\begin{array}{l}\text { Belum adanya Anggaran Dasar } \\
\text { dan Rumah Tangga Masjid }\end{array}$ & $\begin{array}{l}\text { Hal ini memunculkan tidak jelasnya sistem } \\
\text { rekrutmen takmir dan tata kelola masjid. } \\
\text { Akhirnya tidak ada legitimasi sah pihak } \\
\text { mana yang seharusnya mengambil } \\
\text { keputusan terkait kegiatan yang akan } \\
\text { dijalankan masjid. Hal ini juga berdampak } \\
\text { pada munculnya konflik kecil di kalangan } \\
\text { warga. }\end{array}$ \\
\cline { 2 - 4 } & 2. & $\begin{array}{l}\text { Belum adanya struktrur } \\
\text { organisasi masjid }\end{array}$ & $\begin{array}{l}\text { Hal ini berdampak pada tidak jelasnya } \\
\text { pembagian tugas dan wewenang dalam } \\
\text { mengelola masjid. }\end{array}$ \\
\cline { 2 - 4 } & 3. $\begin{array}{l}\text { Belum adanya sistem } \\
\text { perencanaan matang dalam } \\
\text { operasional masjid. }\end{array}$ & $\begin{array}{l}\text { Hal ini menjadikan masjid berjalan tanpa } \\
\text { arah. Misalnya, ketika akan mengadakan } \\
\text { Solat Jumat khotib baru dicari beberapa } \\
\text { hari sebelumnya. }\end{array}$ \\
\hline
\end{tabular}




\begin{tabular}{|c|c|c|c|}
\hline \multirow{3}{*}{$\begin{array}{l}\text { Masalah } \\
\text { Prioritas }\end{array}$} & \multicolumn{2}{|r|}{ Rincian Masalah } & Dampak \\
\hline & 4. & $\begin{array}{l}\text { Belum adanya tata administrasi } \\
\text { dokumen keuangan masjid. }\end{array}$ & $\begin{array}{l}\text { Hal ini memunculkan kecurigaan warga } \\
\text { kepada Takmir dan memunculkan intrik } \\
\text { dan konflik kecil di masyarakat. }\end{array}$ \\
\hline & 5 . & $\begin{array}{l}\text { Belum ada pelaporan keuangan } \\
\text { masjid yang memadai. }\end{array}$ & $\begin{array}{l}\text { Hal ini memunculkan kecurigaan warga } \\
\text { kepada Takmir dan memunculkan intrik } \\
\text { dan konflik kecil di masyarakat. }\end{array}$ \\
\hline \multirow[t]{3}{*}{$\begin{array}{l}\text { Pengelolaan } \\
\text { LAZIS }\end{array}$} & 1. & $\begin{array}{l}\text { Belum ada struktur organisasi } \\
\text { pengelola LAZIS yang terpisah } \\
\text { dengan takmir. }\end{array}$ & $\begin{array}{l}\text { Hal ini menjadikan LAZIS masjid berjalan } \\
\text { tanpa arah. }\end{array}$ \\
\hline & 2. & $\begin{array}{l}\text { Belum adanya peraturan dalam } \\
\text { hal pengelolaan zakat, Infak } \\
\text { dan Shodaqoh di Masjid. }\end{array}$ & $\begin{array}{l}\text { Hal ini memunculkan kebingungan atas } \\
\text { pihak mana yang memiliki otoritas dan } \\
\text { tidak dalam mengelola dana zakat, infak } \\
\text { dan shodaqoh. }\end{array}$ \\
\hline & 3. & $\begin{array}{l}\text { Belum ada pelaporan keuangan } \\
\text { zakat, infak dan shodaqoh yang } \\
\text { memadai. }\end{array}$ & $\begin{array}{l}\text { Hal ini memunculkan kecurigaan warga } \\
\text { kepada Takmir selaku pengelola dana } \\
\text { zakat, infak dan shodaqoh dan } \\
\text { memunculkan intrik dan konflik kecil di } \\
\text { masyarakat. }\end{array}$ \\
\hline
\end{tabular}

Tabel 2. Metode Pendekatan Pemecahan Masalah dan Partisipasi Mitra

\begin{tabular}{|c|c|c|c|}
\hline \multicolumn{3}{|c|}{ Uraian } & \multirow{2}{*}{$\begin{array}{l}\text { Metode Pelaksanaan Pemecahan } \\
\text { Masalah dan Partisipasi Mitra }\end{array}$} \\
\hline No. & Masalah & Solusi & \\
\hline & $\begin{array}{l}\text { Belum adanya } \\
\text { Anggaran Dasar } \\
\text { dan Rumah Tangga } \\
\text { (AD/ART) Masjid }\end{array}$ & $\begin{array}{l}\text { Diberikan pelatihan dan } \\
\text { pendampingan dalam } \\
\text { menyusun Anggaran } \\
\text { Dasar dan Rumah Tangga } \\
\text { Masjid }\end{array}$ & $\begin{array}{l}\text { Diadakan rembuk tim pengabdian } \\
\text { dengan takmir masjid dan akan } \\
\text { disampaikan pentingnya AD/ART } \\
\text { masjid } \\
\text { Dilakukan studi banding terkait } \\
\text { AD/ART masjid dengan masjid } \\
\text { Jogokaryan } \\
\text { Didampingi dalam merumuskan } \\
\text { AD/ART masjid } \\
\text { Partisipasi mitra } \\
\text { Mitra berpartisipasi aktif, menyediakan } \\
\text { tempat, dan membuat surat } \\
\text { permohonan studi banding ke Masjid } \\
\text { Jogokaryan. }\end{array}$ \\
\hline & $\begin{array}{l}\text { Belum adanya } \\
\text { struktrur organisasi } \\
\text { masjid }\end{array}$ & $\begin{array}{l}\text { Diberikan pelatihan dan } \\
\text { pendampingan dalam } \\
\text { penyusunan struktrur } \\
\text { organisasi masjid }\end{array}$ & $\begin{array}{l}\text { Diberikan pemahaman mengenai } \\
\text { pentingnya struktur organisasi masjid } \\
\text { Diberikan penjelasan struktur, jobdisc, } \\
\text { dan peran para anggota takmir masjid } \\
\text { Dilakukan studi banding terkait } \\
\text { AD/ART masjid dengan masjid } \\
\text { Jogokaryan }\end{array}$ \\
\hline
\end{tabular}




\begin{tabular}{|c|c|c|c|}
\hline \multicolumn{3}{|c|}{ Uraian } & \multirow{2}{*}{$\begin{array}{l}\text { Metode Pelaksanaan Pemecahan } \\
\text { Masalah dan Partisipasi Mitra }\end{array}$} \\
\hline No. & Masalah & Solusi & \\
\hline & & & $\begin{array}{l}\text { Dibuatkan pedoman dan panduan } \\
\text { model pengelolaan masjid } \\
\text { Partisipasi mitra } \\
\text { Menyediakan tempat, proyektor, dan } \\
\text { konsumsi untuk pelatihan. }\end{array}$ \\
\hline & $\begin{array}{l}\text { Belum adanya } \\
\text { sistem perencanaan } \\
\text { matang dalam } \\
\text { operasional masjid. }\end{array}$ & $\begin{array}{l}\text { Diberikan pelatihan dan } \\
\text { pendampingan dalam } \\
\text { proses penyusunan } \\
\text { perencanaan operasional } \\
\text { masjid }\end{array}$ & $\begin{array}{l}\text { Diberikan pemahaman pentingnya } \\
\text { proses perencanaan } \\
\text { Diadakan pendampingan dan pelaithan } \\
\text { merencanakan program kerja masjid } \\
\text { selama } 1 \text { tahun } \\
\text { Dibuatkan modul dan dokumen } \\
\text { kelengkapan pengelolaan masjid } \\
\text { ringkas dan aplikatif } \\
\text { Partisipasi mitra } \\
\text { Menyediakan tempat, proyektor, dan } \\
\text { konsumsi untuk pelatihan. }\end{array}$ \\
\hline & $\begin{array}{l}\text { Belum adanya tata } \\
\text { administrasi } \\
\text { dokumen keuangan } \\
\text { masjid. }\end{array}$ & $\begin{array}{l}\text { Diberikan pelatihan dan } \\
\text { pendampingan dalam tata } \\
\text { cara pembuatan dan } \\
\text { pengisian dokumen } \\
\text { pelaksanaan administrasi } \\
\text { keuangan masjid }\end{array}$ & $\begin{array}{l}\text { Dibuatkan modul dan format dokumen } \\
\text { kelengkapan pengelolaan masjid } \\
\text { ringkas dan aplikatif } \\
\text { Diberikan workshop tata administrasi } \\
\text { masjid } \\
\text { Partisipasi mitra } \\
\text { Menyediakan tempat, proyektor, dan } \\
\text { konsumsi untuk pelatihan. }\end{array}$ \\
\hline & $\begin{array}{l}\text { Belum ada } \\
\text { pelaporan keuangan } \\
\text { masjid yang } \\
\text { memadai. }\end{array}$ & $\begin{array}{l}\text { Diberikan pelatihan dan } \\
\text { pendampingan dalam } \\
\text { penyusunan laporan } \\
\text { keuangan masjid }\end{array}$ & $\begin{array}{l}\text { Dibuatkan panduan dan pedoman } \\
\text { pelaporan keuangan masjid. } \\
\text { Dibuatkan format model laporan } \\
\text { keuangan masjid yang sederhana tetapi } \\
\text { memenuhi syarat akuntabilitas yang } \\
\text { baik } \\
\text { Partisipasi mitra } \\
\text { Menyediakan tempat, proyektor, dan } \\
\text { konsumsi untuk pelatihan. }\end{array}$ \\
\hline & $\begin{array}{l}\text { Belum ada struktur } \\
\text { organisasi } \\
\text { pengelola LAZIS } \\
\text { yang terpisah } \\
\text { dengan takmir. }\end{array}$ & $\begin{array}{l}\text { Diberikan pelatihan dan } \\
\text { pendampingan dalam } \\
\text { penyusunan struktrur } \\
\text { organisasi LAZIS }\end{array}$ & $\begin{array}{l}\text { Diberikan pemahaman mengenai } \\
\text { pentingnya struktur organisasi masjid } \\
\text { dan LAZIS yang terpisah } \\
\text { Diberikan penjelasan struktur, jobdisc, } \\
\text { dan peran para anggota takmir masjid } \\
\text { Dilakukan studi banding terkait } \\
\text { struktur LAZIS dengan model Lazismu } \\
\text { Dibuatkan modul pedoman dan } \\
\text { panduan pengeloaan LAZIS di masjid } \\
\text { Partisipasi mitra } \\
\text { Menyediakan tempat, proyektor, dan } \\
\text { konsumsi untuk pelatihan. }\end{array}$ \\
\hline
\end{tabular}




\begin{tabular}{|c|c|c|c|}
\hline \multicolumn{3}{|c|}{ Uraian } & \multirow{2}{*}{$\begin{array}{l}\text { Metode Pelaksanaan Pemecahan } \\
\text { Masalah dan Partisipasi Mitra }\end{array}$} \\
\hline No. & Masalah & Solusi & \\
\hline & $\begin{array}{l}\text { Belum adanya } \\
\text { peraturan dalam hal } \\
\text { pengelolaan zakat, } \\
\text { Infak dan Shodaqoh } \\
\text { di Masjid. }\end{array}$ & $\begin{array}{l}\text { Diberikan pelatihan dan } \\
\text { pendampingan dalam } \\
\text { perumusan peraturan } \\
\text { pengelolaan zakat, Infak } \\
\text { dan Shodaqoh di Masjid }\end{array}$ & $\begin{array}{l}\text { Diberikan pemahaman pentingnya } \\
\text { peraturan, pedoman, panduan, dan } \\
\text { Standar Operasional Pelaksanaan } \\
\text { LAZIS } \\
\text { Dibuatkan modul pedoman, panduan } \\
\text { pengeloaan, dan Standar Operasional } \\
\text { Pelaksanaan LAZIS di masjid } \\
\text { Partisipasi mitra } \\
\text { Menyediakan tempat, proyektor, dan } \\
\text { konsumsi untuk pelatihan. }\end{array}$ \\
\hline & $\begin{array}{l}\text { Belum ada } \\
\text { pelaporan keuangan } \\
\text { zakat, infak dan } \\
\text { shodaqoh yang } \\
\text { memadai. }\end{array}$ & $\begin{array}{l}\text { Diberikan pelatihan dan } \\
\text { pendampingan dalam } \\
\text { penyusunan laporan } \\
\text { keuangan masjid }\end{array}$ & $\begin{array}{l}\text { Dibuatkan panduan dan pedoman } \\
\text { pelaporan keuangan zakat, infak dan } \\
\text { shodaqoh } \\
\text { Dibuatkan format model laporan } \\
\text { keuangan zakat, infak dan shodaqoh } \\
\text { yang sederhana tetapi memenuhi syarat } \\
\text { akuntabilitas yang baik } \\
\text { Partisipasi mitra } \\
\text { Menyediakan tempat, proyektor, dan } \\
\text { konsumsi untuk pelatihan. }\end{array}$ \\
\hline
\end{tabular}

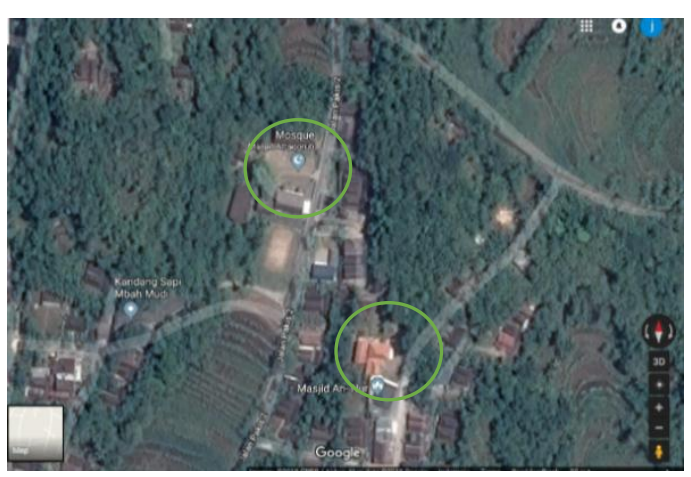

Gambar 1. Peta Lokasi Pelaksanaan Kegiatan

\section{METODE PELAKSANAAN}

Lokasi pelaksanaan kegiatan pengabdian masyarakat adalah di masjid Taqarrub Dusun Pakis 1 dan masjid AnNur di Pakis 2, Desa Dlingo, Kabupaten Bantul, Daerah Istimewa Yogyakarta akan Peta lokasi pelaksanaan program disajikan pada Gambar 1. Prioritas masalah yang telah terindentifikasi pada mitra coba dipecahkan dan diselesaikan dengan melibatkan partisipasi dua mitra tersebut. Pelaksanan pengabdian merancang kegiatan sesuai dengan masalah yang muncul dan dampak negative dari masalah tersebut. Metoda yang akan dilaksanakan untuk memcahkan masalah disajikan pada Tabel 2.

\section{HASIL DAN PEMBAHASAN}

Pelaksanaan program pengandian masyarakat ini diawali dengan pengurusan izin, koordinasi dengan pihak Desa (Kelurahan) Dlingo, Takmir masjid mitra pengabdian kepada masyarakat, sosialisasi kegiatan, pelaksanaan, dan evaluasi kegiatan.

Pada tahap pelaksanaan, penulis yang juga sekaligus sebagai pelaksana melakukan analisis pengelolaan dan tata kelola masjid yang telah berjalan sejauh ini, dan lalu memetakan kelemahan dan kekuarangan yang ada. Selanjutnya, pelaksana melakukan diskusi terkait 
temuan pemetaan tersebut dan merumuskan aktivitas yang akan dijalankan.

Dari analisis pemetaan kelemahan pengelolaan dan tata kelola masjid dan LAZIS, ditemukan bahwa dua masjid mitra program memiliki kelemahan sebagaimana dipaparkan pada Tabel 3. Selanjutnya dari temuan itu, dilakukan pelatihan dan pendampingan oleh pelaksana yang diselenggarakan sebanyak empat pertemuan. Pelatihan dan pendampingan berfokus pada peningkatan kualitas pengelolaan, meliputi: perencanaan programprogram, pengorganisasian, dan evaluasi kegiatan di masjid dan LAZIS. Sementara untuk tata kelola difokuskan kepada penyusunan laporan akuntabilitas yang lebih baik dan transparansi pelaporan keuangan.

Pelaksana juga melakukan inisisasi pembentukan kooperasi syariah dan peningkatan ekonomi ummat melalui masjid dengan berkolaborasi dengan Pengurus Ranting Muhammadiyah Dlingo dan Universitas Muhammadiyah Yogyakarta. Untuk dua kegiatan terakhir ini sebenarnya merupakan permintaan Lurah Desa Dlingo, dan tadinya tidak termasuk dari agenda program kerja pengabdian masyarakat yang diselenggarakan penulis.

Dalam setiap pelaksanaan kegiatan, penulis juga mengadakan Tanya jawab dan diskusi mendalam agar pemahaman dari takmir masjid selaku mitra menjadi lebih mendalam. Setiap sesi Tanya jawab cukup menarik karena biasanya para anggota mitra akan menyampaikan masalah-masalah detail yang dihadapi dan selanjutnya akan didiskusikan untuk menemukan solusi terbaiknya.

Setelah beberapa waktu berjalan, pelaksanaan pengelolaan dan tata kelola masjid dan LAZ di tempat mitra menunjukkan progress yang baik. Hal ini dapat dilihat dari tertatanya proses manajerial masjid dan LAZ, dan adanya pelaporan keuangan dan transparansi yang baik. Kondisi ini menggiring kepada kepercayaan masyarakat yang semakin meningkat yang ditunjukkan dari semakin antusiasnya masyarakat untuk sholat berjamaah di masjid dan mengikuti agenda-agenda masjid. Selain itu, dari informs Lurah Desa Dlingo, konflik dingin antara pengelola masjid dan masyarakat yang skeptic terhadap pengelolaan keuangan masjid dan LAZ menjadi terminimalisir.

\section{SIMPULAN}

Tujuan pelaksanaan pengabdian masyarakat ini adalah untuk meningkatkan kualitas pengelolaan dan tata kelola masjid Taqarrub Dusun Pakis 1 dan masjid An-Nur di Pakis 2 beserta masing-masing LAZ masjid tersebut. Tujuan akhir dari program ini adalah guna memitigasi konflik dingin yang terjadi antara Takmir masjid dan masyarakat yang bersumber dari kurang berjalan dengan baiknya pengelolaan dan tata kelola keuangan masjid dan LAZ.

Dari hasil pelaksanaan program ini, pelaksana menyimpulkan terjadi peningkatan kualitas pengelolaan dan tata kelola masjid Taqarrub Dusun Pakis 1 dan masjid An-Nur di Pakis 2 menjadi lebih baik dan transparan. Konflik terkait prasangka buruk yang muncul dari sebagian kecil masyarakat terkait pengelolaan keuangan masjid dan LAZ mulai termitigasi. Kegiatan masjid juga semakin semarak sehingga memicu ghiroh masyarakat untuk sholat berjamaah di masjid menajdi lebih baik.

\section{UCAPAN TERIMAKASIH}

Penulis mengucapkan banyak terima kasih kepada Lembaga Penelitian Publikasi dan Pengabdian Masyarakat Universitas Muhammadiyah Yogyakarta yang menjadi Sponsor utama pelaksanaan kegiatan pengabdian masyarakat ini. Selain itu penulis juga 
mengucapkan banyak terima kasih dan apresiasi setinggi-tingginya kepada Wakil Rektor UMY Dr. Suryo Pratolo, M.Si., Ak., CA., AAP dan Kaprodi Akuntansi UMY Dr. Ahim Abdurahim, M.Si., SAS., Ak., CA yang turut serta sebagai pemateri pada kegiatan ini. Juga kepada Lurah Desa Dlingo Bapak Bahrun Wardoyo dan segenap aparatur desa serta Pengurus Ranting Muhammadiyah Dlingo Kabupaten Bantul DIY yang memberikan banyak dukungan atas kegiatan ini.

\section{DAFTAR PUSTAKA}

[1] Adil, M. A. M., Mohd-Sanusi, Z., Jaafar, N. A., Khalid, M. M., \& Aziz, A. A. (2013). Financial Management Practices of Mosques in Malaysia. GJAT, 3(1), 23-29.

[2] Alonso, J. M., Clifton, J., \& DíazFuentes, D. (2015). Did new public management matter? An empirical analysis of the outsourcing and decentralization effects on public sector size. Public Management Review, 17(5), 643-660.

[3] Astari, P. P. (2014). Mengembalikan Fungsi Masjid Sebagai Pusat Peradaban Masyarakat. Bina'Al-Ummah, 9(1), 33-44.

[4] Chalikuzhi, A. (2009). Problems and prospects of contemporary zakat management: A qualitative embedded case studies investigation. Unpublished Dissertation.

[5] Endahwati, Y. D. (2014). Akuntabilitas pengelolaan zakat, infaq, dan shadaqah (zis). JINAH (Jurnal Ilmiah Akuntansi dan Humanika), 4(1).

[6] Hafidhuddin, D. (2012). Manajemen Zakat Indonesia. Jakarta: Forum Zakat (FOZ).

[7] Kurniasari, W. (2011). Transparansi Pengelolaan Masjid dengan Laporan Keuangan
Berdasarkan Pernyataan Standar Akuntansi Keuangan (PSAK 45). Muqtasid: Jurnal Ekonomi dan Perbankan Syariah, 2(1), 135-152.

[8] Maghfiroh, S. (2015). Model Manajemen Strategis Pemberdayaan Ekonomi Umat Melalui Zakat, Infak, Sedekah (Studi Kasus pada LAZIS Qaryah Thayyibah Purwokerto). Economic: Jurnal Ekonomi dan Hukum Islam, 5(2), 81-111.

[9] Mamesah, M. (2013). Penerapan PSAK no. 45 pada GMIM Efrata Sentrum Sonder Kaitannya dengan Kualitas Informasi Laporan Keuangan. Jurnal EMBA: Jurnal Riset Ekonomi, Manajemen, Bisnis dan Akuntansi, 1(4).

[10] Muhammad, R. (2016). Akuntabilitas keuangan pada organisasi pengelola zakat (OPZ) di Daerah Istimewa Yogyakarta. Jurnal Akuntansi Dan Investasi, 7(1), 34-55.

[11] Muslim, A. (2004). Manajemen Pengelolaan Masjid. Jurnal Aplikasi llmu-ilmu Agama, 5(2), 105-114.

[12] Nasrudin, M. (2017). Keberterimaan Amil Zakat LAZIS NU dan LAZIS Muhammadiyah terhadap Hegemoni Negara dalam Pengelolaan Zakat. Nizham Journal of Islamic Studies, 5(2), 77-95.

[13] Nikmatuniayah, N. (2012). Akuntabilitas Laporan Keuangan Organisasi Pengelola Zakat Yayasan Daruttaqwa Semarang. Prosiding SNaPP: Sosial, Ekonomi dan Humaniora, 3(1), 523-531.

[14] Nikmatuniayah, N., \& Marliyati, M. (2015). Akuntabilitas Laporan Keuangan Lembaga Amil Zakat di Kota Semarang. MIMBAR, Jurnal Sosial dan Pembangunan, 31(2), 485-494. 
[15] Ulum, I., dan Sofyani, H. 2016. (Akuntansi (Sektor Publik). Yogyakarta: Aditya Media Publishing.

[16] Wahid, H., Ahmad, S., \& Kader, R. A. (2009). Penagihan zakat oleh institusi zakat di Malaysia: mengapa masyarakat Islam tidak berpuas hati?. Jurnal Syariah, 17(1), 89-112.

[17] Wardana, T. I., \& Aribowo, E. (2013). Perancangan Dan Implementasi Sistem Informasi Manajemen Kegiatan Masjid Studi Kasus: Masjid Jogokariyan Yogyakarta. Jurnal Sarjana Teknik Informatika, 1(1). 